\title{
Article
}

\section{The city as critical project - a poetics of collective life}

Holm, Lorens and Mcewan, Cameron

Available at http://clok.uclan.ac.uk/30044/

Holm, Lorens and Mcewan, Cameron ORCID: 0000-0002-0683-1708 (2019)

The city as critical project - a poetics of collective life. arq: Architectural

Research Quarterly, 23 (2). pp. 179-194. ISSN 1359-1355

It is advisable to refer to the publisher's version if you intend to cite from the work. http://dx.doi.org/10.1017/S135913551900023X

For more information about UCLan's research in this area go to

http://www.uclan.ac.uk/researchgroups/ and search for < name of research Group>.

For information about Research generally at UCLan please go to

http://www.uclan.ac.uk/research/

All outputs in CLoK are protected by Intellectual Property Rights law, including Copyright law. Copyright, IPR and Moral Rights for the works on this site are retained by the individual authors and/or other copyright owners. Terms and conditions for use of this material are defined in the policies page.

\section{CLoK}

Central Lancashire online Knowledge www.clok.uclan.ac.uk






\section{arq: Architectural Research Quarterly}

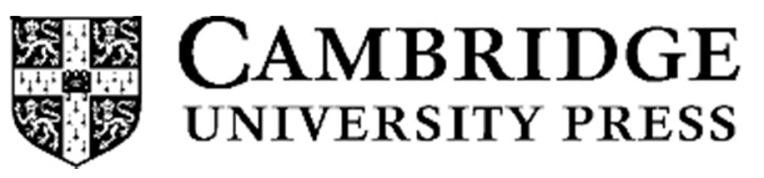

the city is critical project - a poetics of collective life

\begin{tabular}{|r|l|}
\hline Journal: & arq: Architectural Research Quarterly \\
\hline Manuscript ID & Draft \\
\hline Manuscript Type: & Full Paper \\
\hline Keywords: & canonic cities, politics, death drive, civilisation, collective consciousness \\
\hline
\end{tabular}

SCHOLARONE ${ }^{m}$

Manuscripts 


\title{
the city is critical project - a poetics of collective life
}

\begin{abstract}
To find out what society looks like, look at cities. This paper sketches architectural thinking on individual/collective social formations along side projects by the rooms + cities design research unit.
\end{abstract}

\section{Keywords}

canonic cities, politics, death drive, civilisation, architecture, reading, critical project, collective consciousness

\section{Word count}

6200 


\section{Web Abstract}

What does society look like?

Teaching may not be the only way to change built environment thinking but it is one way. Vittorio Gregotti reckoned that the schools were best placed to challenge establishment practices with avant-garde thought.

If you want to know what society looks like, look at our cities, look at their distribution of spaces, their scales, their densities, their flows of people, money, ideas. We use architecture to think the relation between the individual and the collective, and thereby to make a space for politics and public life. This paper sketches the basis for architectural thinking on individual/collective social formations in parallel with city projects by the rooms + cities architecture design research unit - itself a collective endeavor - which begin with the close reading of canonic city plans. These plans constitute the collective intelligence that comprises the discipline and practice of architecture.

The projective vision of architecture is always to place the individual within the infrastructural field of social, political, economic, ideological, and technological forces that define the age (Mies called it zeitgeist). In a world where our two most precious human resources - green land and the political realm - are everywhere under threat by squanderous development practices that favour junkspace typologies and an overly instrumentalised reason that rarely recognises other value in the public realm than monetary value, architecture has the capacity to imagine new forms of city and social life (social housing is not dead, it is not maintained), and new relations of cities to the land.

This paper argues that architecture's task is to save the world by reforming social relations. It would be a mistake to think that architecture can directly determine social relations - nothing is so instrumental - but this paper sets out the terms of the debate and a way to think through the urgencies. 


\section{Rooms+Cities}

Rooms +Cities is a Masters level design research unit at the University of Dundee that conducts design research on the city and its region. The room is the locus of identity and desire, and the city the field that positions it. It aims to build a poetics of density that supports commerce and public life. The principal outputs of the unit are critical city projects that perform acts of reflection upon the city. We draw on the cities and city plans that have achieved canonic status in architectural thought, including the Nolli plan of Rome, Archizoom's No Stop City, Hilberseimer's Hochhasstadt, because they embody the collective intelligence of architecture. The work of the unit congregates around 5 points:

1. Critical Project - At a time when most urban design proposals are ordered to satisfy the private interests of the economy and have little to do with the public staging of politics, what Arendt calls the space of appearance, our only option is the critical project. We call the former, following Tafuri, consumer science, as if the society for whom cities are built are consumers of cities, as if architecture serves society by simply pleasing it. Koolhaas is a critical practice; Fosters is consumer science. Sometimes, we serve society by confronting it with its unpalatable truths (most of us have a traumatic relation to the truth), even if that means biting the hand that feeds us. The critical project is forward facing (there is no other way to face) and relates to the future, even if it draws on the intelligence of the past.

2. Perspectival thinking - We believe in the perspective vision of the author and the projective power of authorship. The author taps into the collective intelligence, what Lacan calls the field of the other, under which cascade a number of other concepts like what the sociologist Maurice Halbwachs (quoted by Rossi) calls collective memory, and Marx class consciousness. An author might be more than one person; an author always reflects the views of more than one person. We believe that what we say about architecture is as important as architecture, because it is one of the lessons of Vitruvius' account of the primitive hut, the first architecture, that architecture is always already formulated as a discourse. We support perspectival thinking because we aim to push back against what Guattari calls our 'paroxysmal era', the 'erosion of subjectivities'.

3. Close reading - We use sampling and montage of plans to generate new projects that are close critical readings of canonic city plans, sites, and their regions. Our methods are graphic, but we borrow the idea of close reading from philosophy, where close reading is a form of writing. Lacan [on Freud] and Derrida [on Heidegger, Hegel, Saussure] are masters of close reading. Close reading is inseparable from close writing; writing is a form of reading. We generate new plans by the close reading of sites and canonic city plans. Close reading requires the formal knowledge of architecture because it involves the sampling of the canon. Reading is not passive; it is generative.

4. The city canon - The collective intelligence of architecture and its historical and future consciousness is defined by the canon of great cities. We mobilize this intelligence by montaging canonic plans into each other and into city sites. The creative power of the author taps into the collective intelligence of architecture to produce forms of urbanism that are recognisable within Western intellectual traditions. (We regard Rossi's history of the city as the collective intelligence of the city.) These plans are developed through iterative drawing and model-making. The plans of new projects are derived from close readings of canonic plans as they confront new sites.

5. Territory-scale thinking - the city is an artefact to which we apply the formal and spatial thinking of architecture. Form is important even if it is a scale that cannot be encompassed from

${ }^{1}$ Guattari, The Three Ecologies (1989/2000 ) p31. In this incredibly prescient passage, he links the erosion of subjectivities with the rise of minority nationalist movements. 
a single position. It makes its edifying impact evident to the inhabitant whether or not it is visual. Frampton refers to megaform and landform. We see it in the practices of Snozzi and Gregotti.

\section{Reading towards a collective architecture}

If you want to know what society looks like, look at our cities, look at their distribution of spaces, their scales, their densities. We use architecture to think the relation between the individual and the collective, and thereby to make a space for politics and public life. This paper sketches the basis for architectural thinking on individual/collective social formations in parallel with city projects by the rooms + cities design unit, which is itself a collective project, that begins with the close reading of canonic city plans in search of the collective body of knowledge that comprises the discipline and practice of architecture.

We begin with canonic city plans - plans that have acquired canonic status in architectural thought, because they accumulate and concentrate architectural knowledge about cities and act as paradigms for projecting architectural thought forward. They ask new questions and open onto new futures. The canonic cities are our source of knowledge about cities, crucial references, and design templates. Rossi touched something similar with his concept of the analogous city. We read the canonic city plans as analogues of each other. Some of these plans represent real cities, some are proposals; they are all critical projects.

Some plans are relatively neutral readings of existing cities, like figure ground plans of Manhattan, Paris, Barcelona. Some make particular claims within architectural discourse about existing cities, like Nolli's reading of Rome as a continuous surface, and Venturi's reading of Las Vegas as a continuous stream of information. Some plans invent new forms of city. These critical projects pose rather than solve problems for cities, and suggest new forms and organisations for responding to them. Piranesi's Campo Marzio uses a fictional antiquity to critique the classical order of cities (contiguity as infrastructure); Archizoom's No Stop City uses the supermarket to critique the impact of commodity culture on cities (inventory as infrastructure). We are particularly interested in avant-garde modern [Le Corbusier, Hilberseimer, Leonidov] and postmodern [Superstudio, Archigram, Archizoom, Ungers, Koolhaas] practices. The fact that these later practices are a critical response to modernism, and hence are historically situated does not limit their insights and creative power for today.

The rooms + cities unit brief is always a social condenser, typically 3000 housing units plus a public space or institution, which allows us to experiment with the relation of individual dwelling to collective form. It is not necessarily public housing, but it is always housing in the public realm because it is designed in a determined relation to a public space that organises it. This space may be an institution, a piazza, or a street grid, so long as it functions to organise social life.

The close reading of city plans is a rooms + cities design research strategy. It begins with the identification of rooms and urban artefacts, and ends with the generation of new forms. Rooms can be big, small, spatial, formal, territorial, cellular, inside, outside, singular, multiple, networked, accessible, inhabitable or not. Reading is a graphic process for exploring the structure and function of these plans, through montage, iterative drawing, modelling, writing and other methods, which lead to new city forms, organisations, and ideas.

We borrow the concept close reading from the text-based practices of philosophy. Probably the most powerful examples of close reading are Jacques Derrida's deconstructive reading of Heidegger, Hegel, Saussure; and Jacques Lacan's reading of Freud, in which he binds Freud's thinking into the whole history of western thought on the mind from the pre-Socratic philosophers to Aristotle, Descartes, Kant, Hegel. One philosopher reads another closely; thus 
philosophy moves forward by reworking its past. Reading is a form of writing. Close reading generates new readings by building thought threads between thinkers and is fundamental to establishing a discourse as opposed to a multitude of solipsists. ${ }^{2}$

For rooms + cities, reading is also generative. We use the process of close reading of canonic cities and sites to generate new part-cities. It is possible to understand all cities as close readings of each other. This idea of the city is related to Hubert Damisch idea of the transformation series [Velasquez to Picasso] and Rossi's idea of the analogous city [Vicenza to Venice]. ${ }^{3}$ For Rossi, all cities are analogous cities; even Manhattan is an analogous city. We should speak rather of analogical thinking, a form of thinking that links all cities to each other, rather than a category of cities. We define the analogical differently from Rossi, who introduced the idea into architectural discourse, because for him it largely took an imaginary form, an operation involving the slippage of images, and not a montage plan form. For Rossi, the locus of analogical thinking is collective memory; the remembering/forgetting of city places is bound up with the condensation and dislocation of images, and analogy defines that slippage. We teach montage not syntax. For Eisenman close reading is syntactical; it leads to the architecture of deconstruction, which is his spatial interpretation of Derrida's deconstructive readings of philosophers. There are thus two main forms of close reading: syntactical [Eisenman] and figural [rooms +cities]. In both cases close reading is transposed to architectural form-making from philosophical text-making.

\section{Statesmen vs consumers}

We are all what Aristotle called statesmen: men and women of the state or polis. If the rooms + cities project has a theoretical underpinning it is the conviction, perhaps now looking simultaneously conservative and radical, that the public space of the city is the foundation of political life. If this project is against something, it is against the particularly virulent form of capitalism - the commodity form of capitalism - that addresses the individual always, and always at the level of the death drive where the individual-ness of the individual is wont to tear apart the ties that bind us into civilisations. This subject of the commodity form, this consumer, is isolated in relation to the alluring commodity, just me and my object. It often takes the form of need ( $I$ need the red ones); it often takes the form of choices between indistinguishable alternatives (I need the red ones, not the blues ones). Not all forms of consumption are destructive. What is destructive is the particular way the commodity form of capitalism isolates us as individuals. Neoliberal approaches to public services use this template of consumer choice. Good health care, for example, is equated with having a choice of doctors, as if, when you need a doctor, we are at the red ones or blue ones cross road.

In 'The Right to the City' (2008), David Harvey argues that, in western democracies, the rights to private property and profit 'trump' the rights to access to the polis, and the public goods that this signifies. His thesis goes in the direction of economics. Forms of development create forms of subject. Suburbanisation creates worker alienated from each other in debt. ${ }^{4}$ In the present context, we take this in a slightly different direction. When I am consumed by my objects, I am isolated in my relation to my object choices. I am no longer a statesman. a subject of the city, determined by its public-ness, its forms and arrangements of spaces. I am determined by, e.g., the books I read; but as a statesmen, I am determined by my (private) voting record, and the relation

\footnotetext{
2 Probably the most poignant reading of Freud is when Lacan struggles to make sense of Freud's enigmatic Wo Es War Soll Ich Werden to which he returns in 5 papers, for a discussion of which, see my Brunelleschi Lacan Le Corbusier (Routledge 2010). For close reading in architecture, see Adam Sharr, ed., Reading Architecture and Culture: researching buildings, spaces and documents (London: Routledge, 2012). The scientific method does for the sciences what close reading does for the humanities, it links individual and individual ideas into discourses.

${ }^{3}$ Cf. Hubert Damisch, The Origin of Perspective (Cambridge MA: MIT Press, 1994).

${ }^{4}$ David Harvey, 'The Right to the City' in New Left Review, (2008), pp. 23-40.
} 
of my flat to my neighbours, and our relation to the street, and our street to our library, tram lines, supermarket, parks, views, sunrises, darkness,.... These relations are given their typical and exemplary definition in the canonic city plans with which we begin our projects. Le Corbusier's Contemporary City for 3 Million and Hilbershiemer's Hochhausstadt were studies in the relation of the private realm of the individual flat to the public realm of the collectively held city. Archizoom's No Stop City is the reductio ad absurdam fantasy of a city as totally commodified field. Houssmann's Paris renovations clarify the confluence of state power and the public realm. The Manhattan grid articulates a clear relation between residential and commercial realms.

\section{Statesmen, reading towards the collective}

\section{Vitruvius}

'Therefore, because of the discovery of fire, there arose at the beginning, concourse among men, deliberation and a life in common. Many came together into one place,...' [p.77] ${ }^{5}$

'...then, from the construction of buildings they progressed by degrees to other crafts and disciplines, and they led the way from a savage and rustic life to a peaceful civilisation.’ [p.85]

Vitruvius' account of the primitive hut in The Ten Books on Architecture tells the story of the birth of architecture from its pre-architectural origins. Primitive men live in the forest until driven out by a catastrophic fire. 'Men, in the old way, were born like animals in forests...' [p77] Once the fire had run its course, the forest dwellers congregate in clearings around the scattered embers. These are the first campfires, catastrophe domesticated. 'In this concourse of mankind,... they fixed words...' [p79] 'And so they generated conversation with one another.' [p79] Once gathered into groups around these originary hearths and words, they invented language so that they could speak to one another, and once speaking, decide to construct homes. Architecture is born with language and fire. Architecture is different from the rude burrowed shelters of primitives, the way language is different from the barking of animals. The trace of speech - what accompanies it as its permanent trace - is writing; and in his extraordinary narrative, Vitruvius presents construction, the construction of architecture, as the writing that accompanies concourse. In other words, for Vitruvius. language constitutes the life in common, and Vitruvius equates language with speech and architecture.

\section{Aristotle and Arendt}

There is a long line of thinking in architectural and political discourse that equates the city-state or polis with the site of public life and politics. This equation has its clearest contemporary statement in the political philosopher Hannah Arendt's reading of Aristotle. The architects and theorists Pier Vittorio Aureli, George Baird, and Kenneth Frampton are largely responsible for introducing her work in architectural discourse. ${ }^{6}$ Politics is about the public resolution of conflict. The agora or marketplace in Aristotle's Athens was originally the space for commerce, intellectual thought, and political debate at a time when democracy was still a new form, perhaps still so new it was not yet recognised. They were working it out as they built it. In The Politics, Aristotle argued that the polis was the natural home of man the political animal. He argues that there are 4 forms of association: the breeding pair, the family, the village, and the state (a kingdom is simply a large family ruled by a despot/father). The polis, where inhabitants are statesmen who meet as equals to publically resolve conflicts of interest, is the social condition of democracy. And the agora is its form. When Aristotle defines man as a 'political animal' motivated by virtue, and distinguishes this political animal from the simple animal - what the political philosopher Agamben will call

\footnotetext{
${ }^{5}$ All page numbers for quotes in this section are from Vitruvius: On Architecture, books I-V (Cambridge: Harvard University Press, 1998) transl. by Frank Granger.

${ }^{6}$ Pier Vittorio Aureli, The Possibility of an Absolute Architecture, (Cambridge MA: MIT Press, 2011); George Baird, The Space of Appearance, (Cambridge MA: MIT Press, 1995); Kenneth Frampton, Labour, Work and Architecture: collected essays on architecture and design, (London: Phaidon Press, 2002).
} 
bare life to distinguish it from a legal life - he makes a similar distinction to Vitruvius between the purposive concourse of men brought together by language, and the primitive condition of the barking solipsist whose togetherness is random. ${ }^{7}$

In The Human Condition (1958), Arendt argues that the city is the formal paradigm for democracy. It is the locus for both what Arendt calls 'the togetherness of people' and the 'space of appearance'. In the togetherness of people (Vitruvius's concourse and Aristotle's association) is power (unity is strength). The space of appearance is where we make our views public, hence the space where they can be scrutinised and debated and resolved, and where we appear accountable for them. This happens in the streets and the debating chamber, both of which appear as architectural forms in our Nolli plans of cities.

\section{Freud}

'The existence of this inclination to aggression,... disturbs our relations with our neighbour and... forces civilisation into such a high expenditure of energy. In consequence of this primary mutual hostility of human beings, civilised society is perpetually threatened with disintegration.' Freud, Civilisation and its Discontents [49]

' $[T]$ he inclination to aggression is an original, self-subsisting instinctual disposition in man,... that... constitutes the greatest impediment to civilisation. ... [C]ivilisation is a process in the service of Eros, whose purpose is to combine single human individuals, and after that families, then races, peoples and nations, into one great unity, the unity of mankind.' [p59]

The discourse on the togetherness is shadowed by another discourse that runs parallel to it but is rarely invoked in political or architectural contexts. The most ambitious attempt to articulate the relation of individual to collective is Freud's account of the death drive. Freud's total opus is a reflection on human nature, the most sustained and internally indexed reflection on our nature, in the history of western thought. ${ }^{9}$ In its ambition, it exposes the ambiguities that dog origninary thinking. Freud made three significant statements about the drives (or instincts as they appear in English translations). Most of us who have encountered the drives are familiar with the dialectic between the mythic terms Eros and Thanatos, love and death, which puts the creative forces of love, life, and creation, in opposition to the forces of death and destruction. This is how the death drive is formulated in Beyond the Pleasure Principle (1920), Freud's second of three statements on the drive, where he argues that the opposing drives toward love and death, pleasure and pain, construction and destruction, inhabit all people.

In Civilisation and its Discontents (1930), Freud puts the drive in opposition to civilisation, as indeed does most of the literature emanating from Civilisation... ${ }^{10}$. This is Freud's final statement on the

\footnotetext{
${ }^{7}$ Aristotle, The Politics (Harmondsworth: Penguin Classics, 1962/1982). The title translates 'things concerning the polis'. The nub of our argument resides in pp55-60, paragraphs 1252a24-1253a29. According to the translators, Sinclair and Saunders, Aristotle was unknown to Republican Rome, so we should not expect Vitruvius to refer to him.

${ }^{8}$ Kenneth Frampton quotes Arendt in his chapters on critical regionalism [togetherness] and globalisation [space of appearance] for which see Modern Architecture: a Critical History. It is unclear whether concourse in social media meets the criteria for Arendt's space of appearance. In a series of oppositions that cascade under Aristotle's distinction between household and state, Vittorio Aureli, reading Arendt and Aristotle, distinguishes politics \& economics in classical thought, the architectural form of the polis \& the management of city growth, and criticises contemporary planning practice as a form of household management of the continuous process of urbanisation rather than what it should be, the formal articulation of settlements for public debate.

${ }^{9}$ Psychoanalysis is rigorously evidence based. The psychoanalytic setting is a linguistic laboratory. Psychoanalysis has an uneasy relation to the sciences because the relations it builds are linguistic, not cause-and-effect. The theory of the drives is ground up theory that emerged out of countless hours of patient observation. It poses a problem for science: a rigorously empirical discipline dedicated to bringing new facts into the world, that does not follow scientific method.

${ }^{10}$ Cf. Felix Guattari, the post-Lacanian analyst and half of the philosopher Deleuze+Guattari, The Three Ecologies (London: Athlone, 1989/2000); Herbert Marcuse, Eros and Civilization: a philosophical inquiry into Freud; Norman O. Brown, Life Against Death, and Nancy Julia Chodorow, 'Beyond Drive Theory: object relations and the limits of radical individualism' in Theory and
} 
drive, and as an architectural proposition, his most definitive. He argues that our natural inclination for aggression against others will tear civilisation apart. Civilisation appears as a form of tie that binds individuals into collective social formations. Freud does not elaborate this tie but we can assume that it includes all the great social institutions, chief among them language, but we could include law, and construction, money, religion, customs, the arts, and all the institutions that regulate life. Civilisation imposes a symbolic infrastructure upon subjects that reigns in our drives, without which we would expend ourselves in a kind of objectiveless fighting and fornicating. In psychoanalytic discourse, Lacan calls this infrastructure the symbolic order or the field of the other. The 'inclination to aggression' resides in each individual and threatens to break those binds. There are passages in Civilisation... where Freud puts the death drive in opposition to love or Eros, rather than civilisation (a regression to Beyond... thinking). Eros here is not the narcissism of the individual (self-love and hence aggression to others); it is the love of others, shorthand for the social field that constitutes civilisation. We are bound to each other, mostly in unconscious ways or ways of which we are largely unaware, because they work though mechanism of language, rather than intention. In post-structural psychoanalytic discourse, the unconscious is the paradigm collective social form, and it collects under it a number of other terms that appear in the architectural and political discourses, including collective memory (Rossi, Halbwachs) and class consciousness (Marx). In the terms of Vitruvius, Eros is near to 'concourse among men'; Eros has the form of speech and construction. And the drive, even when placed in opposition to Eros, seems to be not an other component of the social field, one social pressure among many, but something real that lies outside it, other to it.

In his first statement on the drives, 'The Instincts and their Vicissitudes' (1915), Freud reduces all psychical activity to the incessant repetition of a simple stimulus-response mechanism. All input to the psyche through the senses is stimulus, and the labour of the psyche is its response. The drive appears at the 'frontier between the mental and the somatic'. In a trop not unlike the emergence of architecture as discourse in Vitruvius, the drive inhabits each individual at the locus where opaque body process emerges as representation to the psyche. This repetition is the psychical mechanism in its most originary form, the flywheel that underlies all our psychical activity, of which language is the main medium but which includes all human activities - art and science, social political and economic - that organise collective life.

In Civilisation..., drive theory is presented as a dialectic between the collective, which is the locus of civilisation, in all its particularity and universality, its creation and constructivity (Rossi defines the architecture of the city as construction) and the individual, which lies outside it, and is the locus of a form of deaf, dumb, and numb repetition that undoes all that is civilisation and all that it signifies. Freud calls this inclination Trieb or drive, to distinguish it from Instinkt or animal instinct. In his argument drive plays the role of what is simple and pre-significant vis-à-vis a civilisation that is constructed and signifying. Freud puts civilisation in the singular: it is a collective fiction, a fictional collective. Discontents is plural: reality is a multitude of individuals. A fictive unity is put in dialogue with a real multitude. As if we are all naturally individuals, the reality of the body, my body different from yours. And we share a fiction that we are a civilisation, and what civilisation is protecting us against is our own nature. ${ }^{11}$

\section{Lacan reading Freud}

Civilisation is not a fiction but it is, to borrow Lacan's term, symbolic, which distinguishes it from other sorts of fictions that are imaginary, and from the opaque material world. In The Four

Society, 14 (1985) 271-319, which discusses these two latter texts.

${ }^{11}$ Sigmund Freud, 'Instincts and their Vicissitudes (1915)', in Sigmund Freud: on Metapsychology: the theory of psychoanalysis, edited by A. Richards and J. Strachey (London: Penguin, 1991), pp. 113-38; Beyond the pleasure principle (London: Hogarth Press and Institute of Psycho-Analysis, 1920/1974); Civilization and its Discontents, (London: Hogarth Press and Institute of PsychoAnalysis, 1930/1975). Page numbers in this section from Civilization.... 
Fundamental Concepts of Psychoanalysis (1964), Lacan argues that Freud's concept of the drive is as much a symbolic construct as is civilisation. He calls the four components (pressure, aim, object, source) by which Freud defines the drive in '...Vicissitudes' a montage. What links them is the compelling nature of the assemblage, and not logic or cause. Lacan argues furthermore that Freud cannot articulate the recursive 'circuit' or 'path' of the drive, in effect driven behaviour, without recourse to the linguistic forms of the active, passive, and reflexive verb forms. ${ }^{12}$ Lacan takes Freud's English translators to task for translating both Trieb and Instinkt as instinct, thereby blurring a critical distinction in Freud's thought between what is constructed and what is the natural behaviour of animals. ${ }^{13}$ According to Lacan, Freud's individual - the locus of the drive is as much an artefact or construct of civilisation - as is civilisation. The subject of psychoanalysis, takes the form of a speaking being [Lacan's parle-être], an individual availing itself of a collectively held linguistic culture, and it must already be bound into civilisation, in order to articulate itself as individual.

\section{Rereading Vitruvius}

The same logic of origins that is at work In Freud's account of civilisation is at work in Vitruvius' account of architecture, and indeed in all originary thinking. In Freud, civilisation has to invent an unbound individual (an oxymoron?) in order to explain itself by reference to an origin. Civilisation has to expel this fictive individual in order to be civilisation; thereafter, this individual persists as a kind of absent presence that haunts civilisation. This individual is a construction, but is asked to play the role of an origin. It appears as an outsider, but turns out to be internal to the logic of civilisation. The logic is spatial, but it is masked by temporal metaphors. It appears in Derrida's deconstructive reading of phenomenology as a meaning that is always already deferred, an absent presence that has haunted western philosophy since Plato. It appears in the political philosopher Giorgio Agamben's account of the origins of the concept of the law and the force of law, in the state of exception or emergency that is precisely the moment when the power of the law is revoked. It appears in one of Lacan's few short statements on architecture, architecture, like painting, is organised around emptiness. This individual is not the origin, but the negated present [Derrida's formula] of civilisation, this absent figure that civilisation has to construct at its centre and then expel, disown, negate, in order to be civilisation. ${ }^{14}$

Architecture binds individuals because projects are - in Arendt's terms - bigger than what any one person can construct and they outlast the mortality of individuals ${ }^{15}$. In Vitruvius, civilised people construct a pre-linguistic individual to exclude, in order to make concourse amongst speaking subjects intelligible. The individual cannot experience itself as an individual until it is already part of a larger linguistic entity. A civilisation styled as a social group modelled on the family, i.e. a grouping around a campfire or hearth but in reality a grouping of many families, and no longer an extension of the breeding pair, who now have language, in other words, a linguistically constituted group who have moved beyond the yelping of animals, invent a presocial formation, the unattached wandering yelping forest-bound fire-harassed individual, in order to make intelligible to themselves their current condition of concourse. The individual is born with language and architecture; language and architecture are the infrastructures that bind

\footnotetext{
${ }^{12}$ Jacques Lacan, The Four Fundamental Concepts of Psycho-Analysis (New York: Norton Press, 1981) pp, an argument too complex for this author.

${ }^{13}$ Jacques Lacan, 'The Subversion of the Subject and the Dialectics of Desire in the Freudian Unconscious (1960)', in Ecrits: the first complete edition in English, (New York: W W Norton 2006), pp. 671-702. Most animals are by nature associative. ${ }^{14}$ Jacques Derrida, 'Differance', in The Margins of Philosophy, (Chicago: University of Chicago, 1982), pp. 1-27; Giorgio Agamben, State of Exception (Chicago \& London: University of Chicago Press 2005); Jacques Lacan, The Seminar of Jacques Lacan, Book VII: The Ethics of Psychoanalysis 1959-1960 (NYC: Norton, 1992). Derrida uses a similar formula to account for how Marxist thought continues to haunt philosophical thinking, especially after the fall of the wall for which see: Derrida, Specters of Marx: The State of the Debt, the Work of Mourning and the New International, transl. by Peggy Kamuf (Routledge 1993/1994).

${ }_{15}$ Cf. Frampton quoting Arendt.
} 
individuals; the negativity they contain which threatens them from the inside, is interpreted as the retroactive construction of an absent presence.

There is an analogous relation between language and architecture: Vitruvius' parle-être talking around their campfire and the Vitruvian hut that we build and habit together. We are bound to each other by conversation and by the project, designed and constructed. Language is a form of construction that binds us together, only we tend not to recognise it as such because we live in a linguistic environment, it is our air, it is all around us, as opposed to a crafted artifact that we place before our eyes and hands. Hannah Arendt talks about the importance of work (Victorian good works) which put things into the world that outlast us, and distinguishes work from labour that is completely exhausted each day in survival (the drive is labour). She critiques Marx for flubbing this distinction. ${ }^{16}$ Work produces civilisation and its enduring artifacts. Although it may seem that our speech disappears like labour, gone without remainder as soon as it does its job, and writing - writing unlike speech, leaves a trace - is a slim artifact, speech and writing put ideas into the world which are as constructional and artifactual as building. Guattari argues for an ecology that preserves non-corporeal beings like ideas as well as living beings. People congregate around ideas as much as they congregate around buildings and camp fires.

${ }^{16}$ Cf. Frampton quoting Arendt. 


\section{Rooms + cities $\&$ its cities}

Rooms + cities is a form of practice comprising architectural design and texts to produce projects that are critical readings of cities. We distinguish the critical practice from what we call following Tafuri - consumer science. As if societies were consumers of cities, and architecture served it by simplistically giving it what it wants as opposed to giving it critical reflection, health and well-being, and deferred happiness. Koolhaas is a critical practice; Foster is consumer science. Sometimes, we serve society best by biting the hand that feeds us. The critical project is future facing, even if it draws on the intelligence of the past. There are other practices that produce texts with their designs, but they tend to reproduce, and hence reinforce rather than critique, the consumer quo. ${ }^{17}$

We understand the critical project in terms of the dialectic between room and city: the room is the locus of occupation; the city is the field within which occupation occurs. The room is the place of an individual; the collective is infrastructural because infrastructure allows it to happen. We define infrastructure to include the road and cabling network, all forms of communication without which collective consciousness would not be possible; we include also archives, and the continuous space-shaping surface of Rome's fabric, such as it was the principal achievement of the Nolli plan to visualise. The Nolli plan demonstrated to architecture that Rome is nothing if not an infrastructure of surface.

The rooms + cities moniker is taken from Lacan's formula for the subject of psychoanalysis: egounconscious. Lacan crosses Freud's two formulas or topographies for the psyche. Freud's first topography, ego/id, was about agency; the second, conscious/unconscious, are functions. The unconscious is not a mythic place but the collective field where we communicate our desire all the time, under the radar. We only become aware of it when there are divergences between subjects, like slips of the tongue. The conscious I want of the ego has a position in space and in discourse, but what I say is never precisely what you hear or what I mean. The unconscious is thus the infrastructural field where desire, is articulated and always missed.

One of the demands made upon architecture by society is to articulate, by spatial and material means, this collective life and consciousness. In rooms + cities, we regard the binary individualcollective as a theoretical frame with which to understand the myriad social formations that manifest through social and political practices and institutions. By constructing the city, architecture spatialises the social field and thus makes visible what might otherwise remain hidden within the function of social and political practice. Construction is the particular form of close critical reading of the city that is proper to architecture. Other practices - fiction for instance - do it too, but differently. ${ }^{18}$

We can read the relation of individual to collective in the plans of the mature industrial cities of the contemporary west, which have - during the history of industrial development and labour relations - worked out forms and organisations that are dense enough to support commerce and togetherness of political life. In Manhattan, this relation of individual to collective is articulated in

\footnotetext{
${ }^{17}$ Lacan used to quip that the ego has a traumatic relation to the truth, and will go to any measures to shield itself from it. We refer to practices that Peter Cook calls 'the biscuit boys'. Tafuri does not say 'consumer science'. We 'distill' the phrase from a reading of Manfredo Tafuri, Architecture and Utopia: design and capitalist development, (Cambridge MA: MIT Press, 1976) and from Pier Vittorio Aureli, The Possibility of an Absolute Architecture, (Cambridge MA: MIT Press, 2011) which is itself a reading of Tafuri.

18 Two great novels of New York: Paul Auster, New York Trilogy (1985/86); John Dos Passos, USA Trilogy (1930/32/36). Two great novels of Paris and London: George Orwell, Down and Out in Paris and London (1933); Charles Dickens, $A$ Tale of Two Cities (1859).
} 
the two scales of the street grid, which define residential and commercial space. ${ }^{19}$ It can be shown that all architectural expression of these two social forms follow from the scale change between north-south avenues and east-west crosstown streets. The turn of a corner accompanied by the change in scale forms a palpable spatial threshold between residential and commercial. This is the particular way it is articulated in Manhattan, different from how the Berlin block does it, or the Paris boulevard section. ${ }^{20}$ Paradoxically, the Manhattan grid is the paradigm commodity form. The 1811 Commissioners Plan divided a wooded and agrarian Manhattan into rectangular blocks, and each block into rectangular plots for sale. These plots, which define the smallest unit of building, are still visible in the fire marshal plans of Manhattan. They define the narrow deep party wall townhouse typology; the typical apartment building cobbles several plots together. Their long sides define the broad commercial fronts on the avenues.

That the relation of the individual to the collective is central to architectural discourse on cities can be seen in the great critical city projects of the $20^{\text {th }}$ Century. In the City for 3 Million Inbabitants (1922) and its subsequent worked examples like the Plan Voisin de Paris (1925), one of the critical issues was to design a form of dwelling adequate to the form of the city plan. It was this relation of dwelling unit to city articulated in Le Corbusier's project that Hilberseimer criticised in his Hochbausstadt counter-project (1924). It is a question of how the city collects dwellings into a purposive and identifiable relationship to each other and to the public realm, rather than - his reading of Le Corbusier - a romantic visual relation. In The History of the City (1980), Leonardo Benevolo argues that the exploration of new forms of housing - hence new forms of association - was the defining project of modern architecture. He called it 'social research', and it is significant that almost all the major housing projects, both real and speculative proposals, were situated within a city context where the relation of the housing to city was under scrutiny alongside problems of household accommodation and economy.

When Venturi launched his thesis about Las Vegas by putting a picture post card on the Nolli plan, he was not only adding Vegas to the city canon, he was also calling for a change in values. The lingering doubt about Venturi's thesis does not have to do with his reading of Las Vegas as information infrastructure, but the loss of a paradigm of social life. What modern architecture loves about Rome, is not the historical form and style but the street life. Venturi is replacing the value we attribute to social life - what we might call the political value of the city - with commodity value. We cannot prevent the space for social life from becoming a commodity for consumption, but we can at least be cognizant of what is happening. The infrastructural surface of Rome is about creating space for the appearance of collective life; the information roadways of Las Vegas - and the new urbanism that is consequent on Las Vegas thinking - are about satisfying the I want of the individual. There is a difference between a collective unity and a multitude of individuals, and the construction of the city either brings individuals together into collective action or it isolates them in their individual wants. That Frampton understood

\footnotetext{
${ }^{19}$ In Manhattan the commercial realm is synonymous with the public realm. There are almost no piazzas. And most of those that there are, like Rockefeller Centre or the Seagram setback provision, are private property. When people exercise their right to congregate in protest, they do it by marching down the avenues. In The Life and Death of American Cities, Jane Jacobs got it critically wrong when she criticised the long block from the perspective of her Greenwich Village window. The Manhattan long block which functions in relation to the short commercial block, is one of the most effective neighbourhoods in the world.

${ }^{20}$ The residential neighbourhoods of Manhattan are defined by turn of the century residential buildings averaging between 6 and 10 stories that line the long single lane, one-way crosstown streets. The relation of individual and collective begins with a typical apartment plan. The facades of these buildings unify 10 floors of apartments into a single identity. The facades line the crosstown streets. These streets, which have the scale, leafy light, and character of neighbourhoods, frame into the broad commercial avenues (4 lane, two way) that define a continuous retail storefront.
} 
Venturi's gesture as an attack on the political value of the city is clear from the way he castigates Venturi for saying that Americans do not need piazza because they have TV. ${ }^{21}$

\section{A conclusion on collective consciousness and renunciation}

The challenge for architecture is to explore new forms of collective consciousness in an age of commodity capitalism. This is the urgent project of our times. What is at stake is how architecture articulates the relation between the individual and the collective. The one and the many. The multitude of ones that resist collectivisation. The many that form a unity with an intelligible grammar, a position and direction, an urgency, a form. Architecture articulates this relation spatially. Architecture is in dialogue with neighbouring practices in the arts, humanities, and social sciences. We draw our urgency from our incapacity to stop damaging ourselves by damaging our environment. Although Freud wrote his most definitive statement on civilisation at a time when the long shadow of fascism was already cast upon Vienna, if he were writing today, he might have seen this aggression against ourselves and others in our damaging development practices. Commodity capitalism is capitalism's most virulent form because it reduces us to individuals. The problem is not capitalism as a way of organising development; the problem is the commodity form (commodity communism is no better than commodity capitalism).

We regard the public life of the city as tantamount to political life. Geddes and Mumford regarded the city as the single largest and most important artefact of our civilisation, and its function is to give togetherness a determined form with a purposive and significant relation to individuals. We read this relation in our canonic city plans. Environmental damage is a failure of public life, not a failure of technology, even if technology can ameliorate it. We cannot disengage our treatment of the environment from public life. Indeed Guattari regarded them as inseparable. This paper has attempted to interpret what collective life might be, in architectural terms. This has involved reading canonic plans as forms of collective life. And then re-inscribing these plans into new sites. We need to develop new forms of living together, with implications for forms of governance, so that we can agree an approach to development that renounces the profligate exploitation of our land and public realm. ${ }^{22}$

The intelligence of Vitruvius' and Aristotle's parallel accounts of the formation of architecture and society is that they amplify how ambiguous our relation to nature is, an ambiguity they obscure by giving this formation the temporal form of an event. As if we have emerged from a state of nature, rather than being always already natural. The intelligence of drive theory is that it understands destruction to be internal to civilisation and not in opposition to it, an internal core that has to be contained bracketed rejected. It puts the damage we do to the public realm and to the environment onto a universal template for what it is to be human. It is human to regard civilisation-building as arduous and difficult to sustain because it involves togetherness when what we would really rather do is what we always do, flub out in front of our screen. Alone.

\footnotetext{
${ }^{21}$ Kenneth Frampton, 'Towards a critical regionalism: 6 points for an architecture of resistance', in Anti-Aesthetic: Essays on Postmodern Culture, edited by H. Foster (Seattle: Bay Press, 1983), p25. Frampton writes 'The manipulative bias of such ideologies [new urbanism] has never been more openly expressed than in Robert Venturi's Complexity and Contradiction in Architecture (1966) wherein the author asserts that Americans do not need piazzas, since they should be at home watching television. Such reactionary attitudes emphasize the impotence of an urbanised population which has paradoxically lost the object of its urbanization.' Entertainment is the opiate of the masses.

${ }^{22}$ In The Three Ecologies (1989/2000), Guattari, argues that there are three ecologies, the natural, the social, and the psychical and we cannot resolve one without resolving the other two. His reading of Civilisation..., that it is threatened by the narcissism of individuals. One of his most important contributions to psychoanalytic thought is to link the psyche to ecological consciousness. Ecosophy recognises the 'entire mental ecology' that is 'in crisis' and includes 'incorporeal species', like ideas and human discourses and practices.
} 
It is possible to understand the spatial expression of architecture, which usually takes the form of a container, its preoccupations with the envelope, with cladding (thank you Semper, thank you Loos), as an allusion to the internal resistance necessary to support civilisation. We may need to clad our profligate ways by creating public forms of renouncing them (any other form of containment is repression, and when did that work?). It may be that the paradigm form of collective consciousness for today is a form of renunciation, and we may need to construct a city in which renunciation can appear as politic. Either renunciation or else we need to write new narratives of death and forgiveness, a kind of Civilisation... update, because if we cannot stop damaging our green and public environments, we will need to beg the forgiveness from our children for what we could not help but do. The drive is either displaced by a form of truth commission or is sublimated as narrative. In either case, it needs a space. 


\section{References}

Giorgio Agamben, Homo Sacer: Sovereign Power and Bare Life (Stanford, CA: Stanford U Press, 1998).

Giorgio Agamben, State of Exception, (Chicago: University of Chicago Press 2005).

Hannah Arendt, The Human Condition, (Chicago: University of Chicago Press, 1958).

Aristotle, The Politics, (Harmondsworth: Penguin Classics, 1962/1982).

Pier Vittorio Aureli, The Possibility of an Absolute Architecture, (Cambridge MA: MIT Press, 2011).

George Baird, The Space of Appearance, (Cambridge MA: MIT Press, 1995).

Leonardo Benevolo, History of the City, (Cambridge MA: MIT Press, 1980).

Nancy Julia Chodorow, 'Beyond Drive Theory: object relations and the limits of radical individualism', Theory and Society, 14 (1985), 271-319.

Hubert Damisch, The Origin of Perspective, (Cambridge MA: MIT Press, 1994).

Gilles Deleuze, 'Postscript on the Societies of Control', October, 59 (1992), 3-7.

Jacques Derrida, 'Differance', in The Margins of Philosophy, (Chicago: U of Chicago, 1982), pp. 1-27.

Jacques Derrida, Specters of Marx : the state of the debt, the work of mourning and the New International, (New York, London: Routledge, 1994).

Peter Eisenman, 'From Object to Relationship: Giuseppe Terragni- Casa Giuliani-Frigerio', Perspecta, (1971), 38-61.

Dylan Evans, An Introductory Dictionary of Lacanian Psycho-Analysis, (NYC: Routledge, 1996).

Kenneth Frampton, Modern Architecture: a critical history, (London: Thames and Hudson, 1980 1985).

Kenneth Frampton, 'Towards a critical regionalism: 6 points for an architecture of resistance', in Anti-Aesthetic: Essays on Postmodern Culture, edited by H. Foster (Seattle: Bay Press, 1983), pp. 16-30.

Kenneth Frampton, 'The status of man and the status of his objects', in Labour, Work and Architecture: collected essays on architecture and design, (London: Phaidon Press, 2002), pp. 25-43.

Sigmund Freud, 'Instincts and their Vicissitudes (1915)', in Sigmund Freud: on Metapsychology: the theory of psychoanalysis, edited by A. Richards and J. Strachey (London: Penguin, 1991), pp. 113-38.

Sigmund Freud, Beyond the pleasure principle (1920), (London: Hogarth Press and Institute of Psycho-Analysis, 1974).

Sigmund Freud, Civilization and its Discontents (1930), (London: Hogarth Press and Institute of Psycho-Analysis, 1975).

Mario Gandelsonas, 'From Structure to Subject: The Formation of an Architectural Language', Oppositions, (1978), 6-29.

Vittorio Gregotti, New Directions in Italian Architecture, (London and New York: Studio Vista Limited and George Braziller, 1968).

Felix Guattari, The Three Ecologies (1989), (London: Athlone, 2000).

Maurice Halbwachs, The Collective Memory, (New York: Harper \& Row Colophon Books, 1950/1980).

David Harvey, 'The Right to the City', New Left Review, (2008), 23-40.

Lorens Holm, Brunelleschi Lacan Le Corbusier: architecture, space, and the construction of subjectivity, (London: Routledge, 2010).

Rem Koolhaas, Delirious New York: A Retroactive Manifesto for Manhattan, (New York: The Monacelli Press, 1978/1994).

Rem Koolhaas, 'Junkspace', October: Obsolescence A Special Issue, (2002).

Jacques Lacan, The Four Fundamental Concepts of Psycho-Analysis (Seminar XI), (NYC: Norton, 1981).

Jacques Lacan, The Seminar of Jacques Lacan, Book. VII: The Ethics of Psychoanalysis 1959-1960, (NYC: Norton, 1992).

Jacques Lacan, 'The Subversion of the Subject and the Dialetice of Desire in the Freudian Unconscious (1960)', in Ecrits: the first complete edition in English, (NYC: Norton, 2006) pp. 671-702.

J. Laplanche and J-B. Pontalis, The Language of Psycho-Analysis, (London: Hogarth Press \& Institute of Psycho-Analysis, 1973). Le Corbusier, Oeuvre Complete, (Zurich: Les Editions d'Architecture (Artemis), 1986).

Herbert Marcuse, Eros and Civilization: a philosophical inquiry into Freud, (Boston: Beacon Press, 1974).

Aldo Rossi, Architecture of the City, (Cambridge, MA: MIT Press, 1982).

Manfredo Tafuri, Architecture and Utopia: design and capitalist development, (Cambridge MA: MIT Press, 1976).

Manfredo Tafuri, 'The dialectics of the avant-guarde: Piranesi and Eisenstein', Oppositions, (1977).

Robert Venturi, Denise Scott Brown and Steven Izenour, Learning from Las Vegas: the forgotten symbolism of architectural form (Cambridge: MIT Press, 1986).

Vitruvius, On Architecture, books I-V (Cambridge: Harvard University Press, 1998).

\section{Image Captions}

1 The discourse on the city as a collective artifact. Three texts. Images arranged by Lorens Holm.

2 The plan is the signifier of social relations in the discourse on the city: The agora of Athens, Sforzinda, Rome, Manhattan. Images arranged by Lorens Holm.

3 Fergus Low, Robbie Miller, Elspeth Tayler, Analogical Ravenscraig, Session 2015-16. A montage of fragments of Nolli’s Rome, Ledoux's Saltworks and Ungers' Archipelago City condense into city islands - analogical figures. Images arranged by Cameron McEwan.

4 Caitlin Bowers, Kieran McAdam, Fennella Nkansah, Danielle Reid, Ravenscraig: Heterogeneous-Mat, Session 2016-17. A close-reading of a post-industrial site densified with Piranesian objects combined with Manhattan blocks.Images arranged by Cameron McEwan.

5 Matthew Gadie, Kirsten Pont, Athina Ralli, Li Zhen Ng, Newbridge: Slabs and Frames, Session 2016-17. Long slabs mix with monumental infrastructural typologies to organise the horizontality of a city edge site. Images arranged by Cameron McEwan. 


\section{Images}
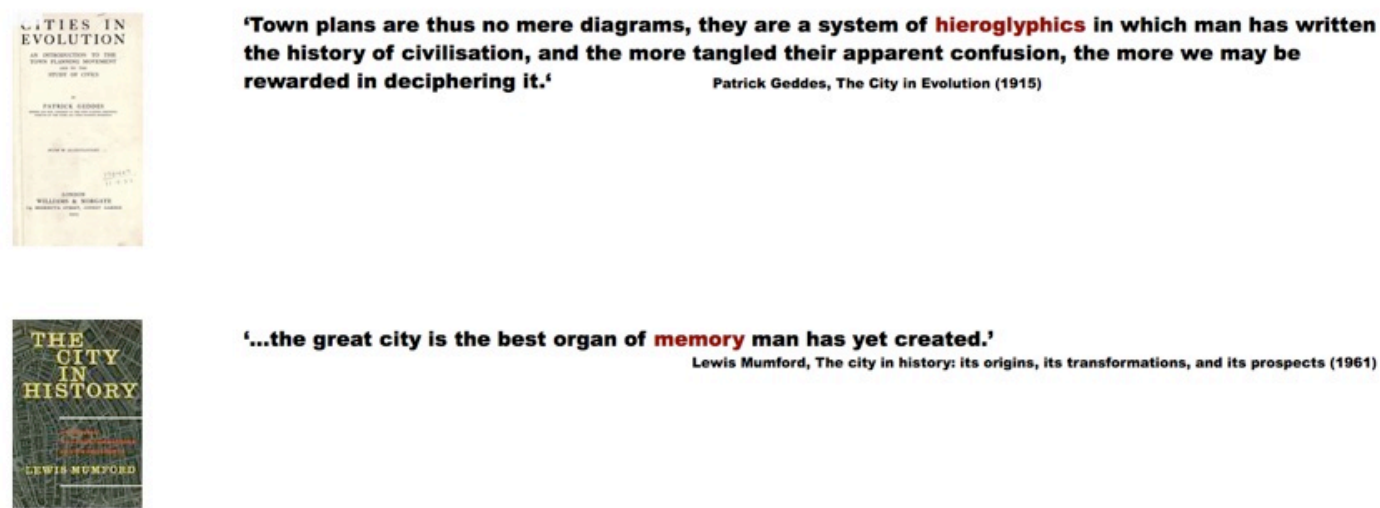

'...the great city is the best organ of memory man has yet created.'

1 The discourse on the city as a collective artifact. Three texts. Images arranged by Lorens Holm.
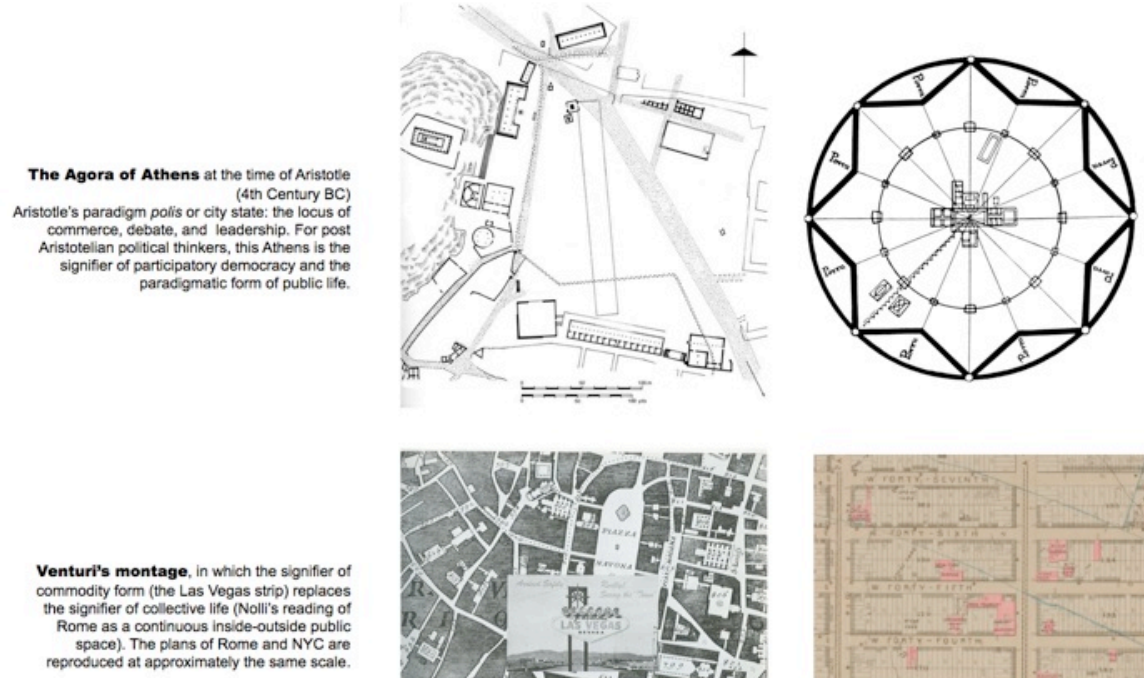

Plan of Sforzinda published in
Filarete, Trattato di Architetura (ca

An ideal city plan in which the

An ideal city plan in which the
compelling nature of its geometric
organisation is made to coincide with

'Our description of the city will be concerned primarily with its form.... the city seen primarily as a gigantic man-made object, a work of engineering and architecture that is large and complex and

'All great manifestations of social life have in common... the fact that they are born in unconscious life. This life is collective....
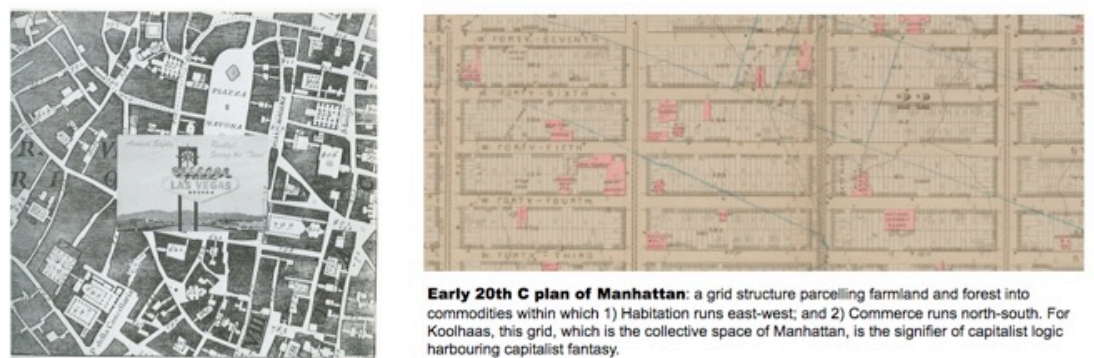

Early 20th $\mathbf{C}$ plan of Manhattan: a grid structure parceling farmland and forest into


Koolhass, this grid, which is the collective space of Manhattan, is the signifier of capitalist logic
harbouring capitalist fantasy.

2 The plan is the signifier of social relations in the discourse on the city: The agora of Athens, Sforzinda, Rome, Manhattan. Images arranged by Lorens Holm. 

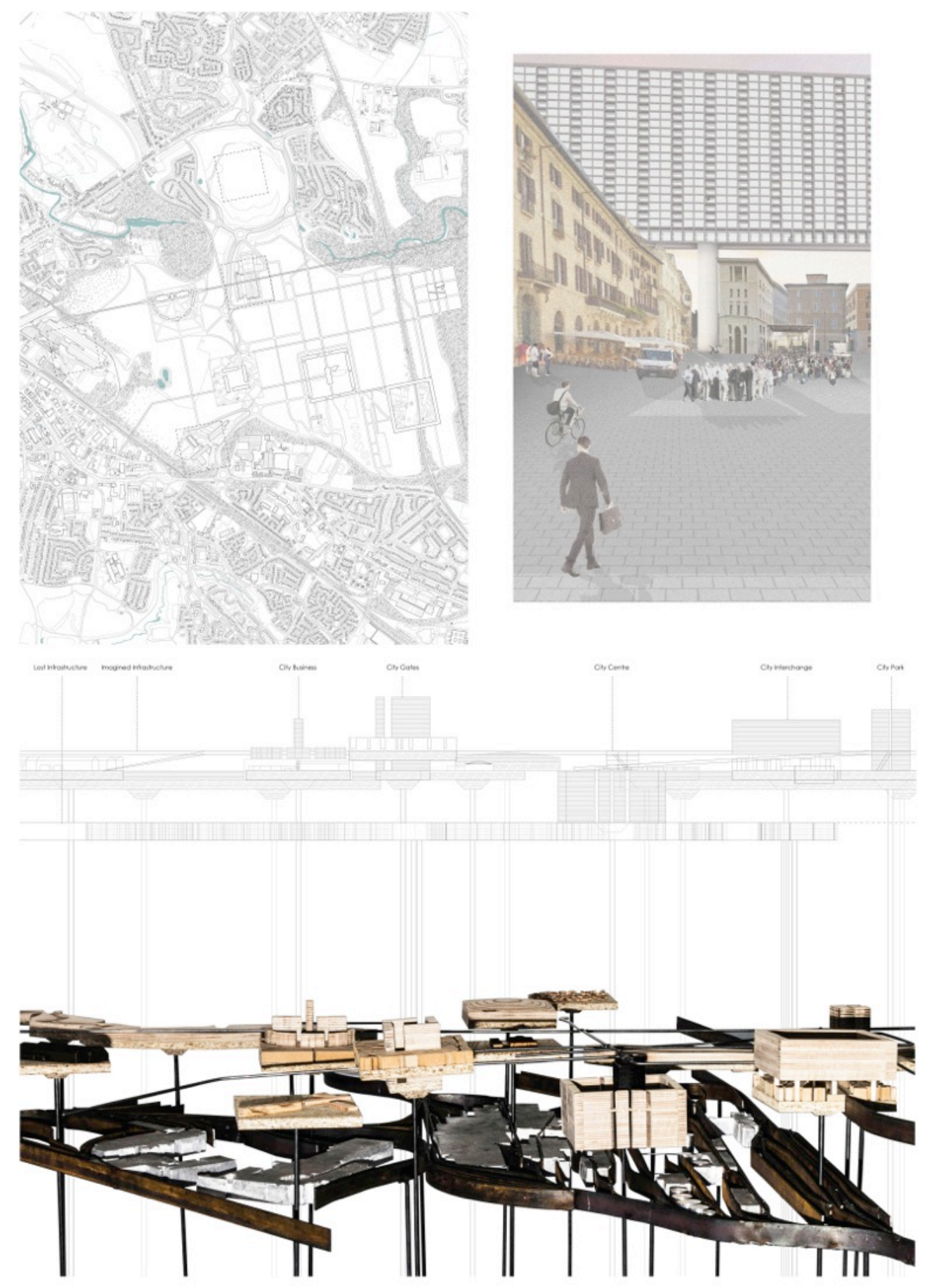

3 Fergus Low, Robbie Miller, Elspeth Tayler, Analogical Ravenscraig, Session 2015-16. A montage of fragments of Nolli's Rome, Ledoux's Saltworks and Ungers' Archipelago City condense into city islands - analogical figures. Images arranged by Cameron McEwan. 

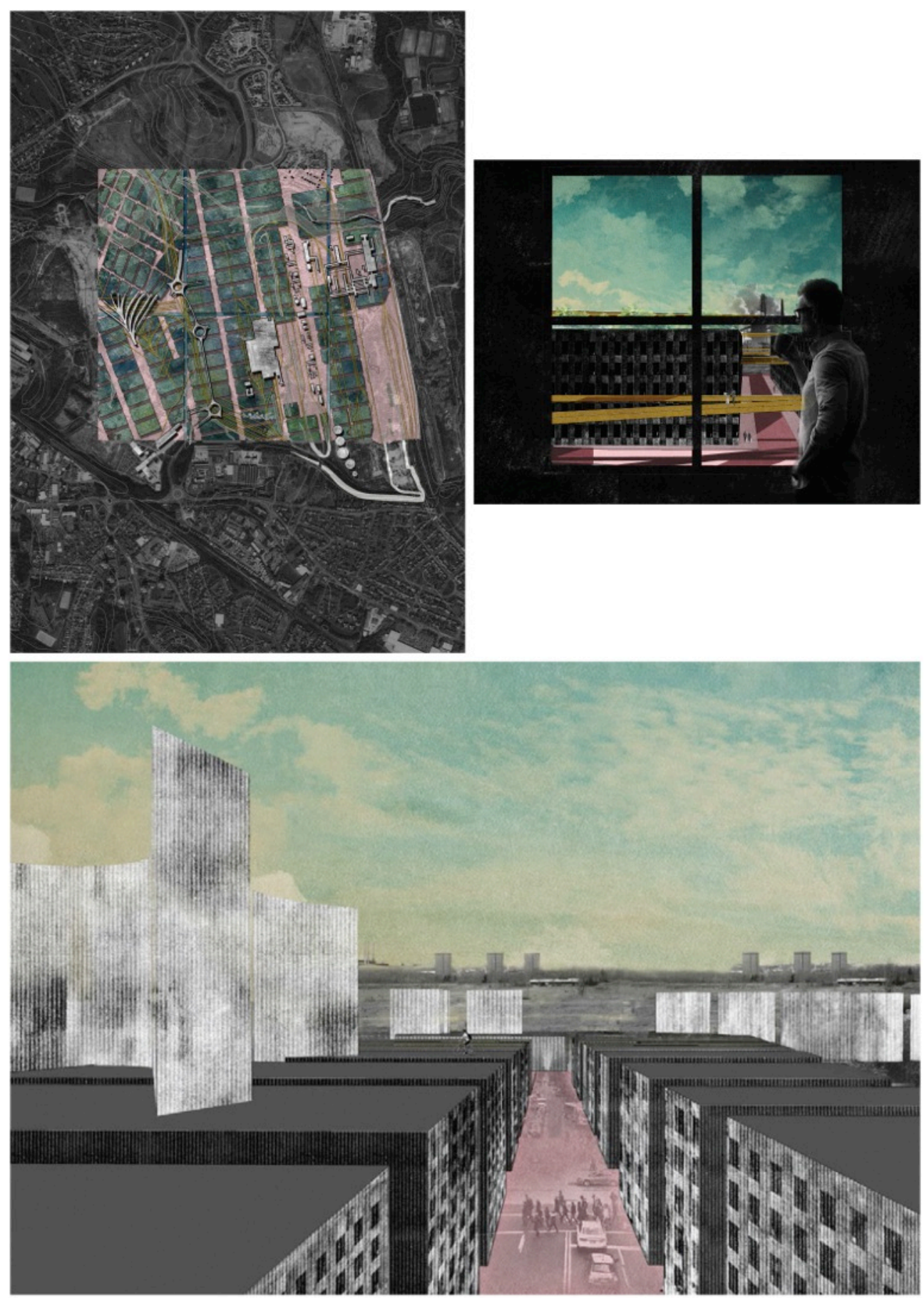

4 Caitlin Bowers, Kieran McAdam, Fennella Nkansah, Danielle Reid, Ravenscraig: Heterogeneous-Mat, Session 2016-17. A close-reading of a post-industrial site densified with Piranesian objects combined with Manhattan blocks.Images arranged by Cameron McEwan. 

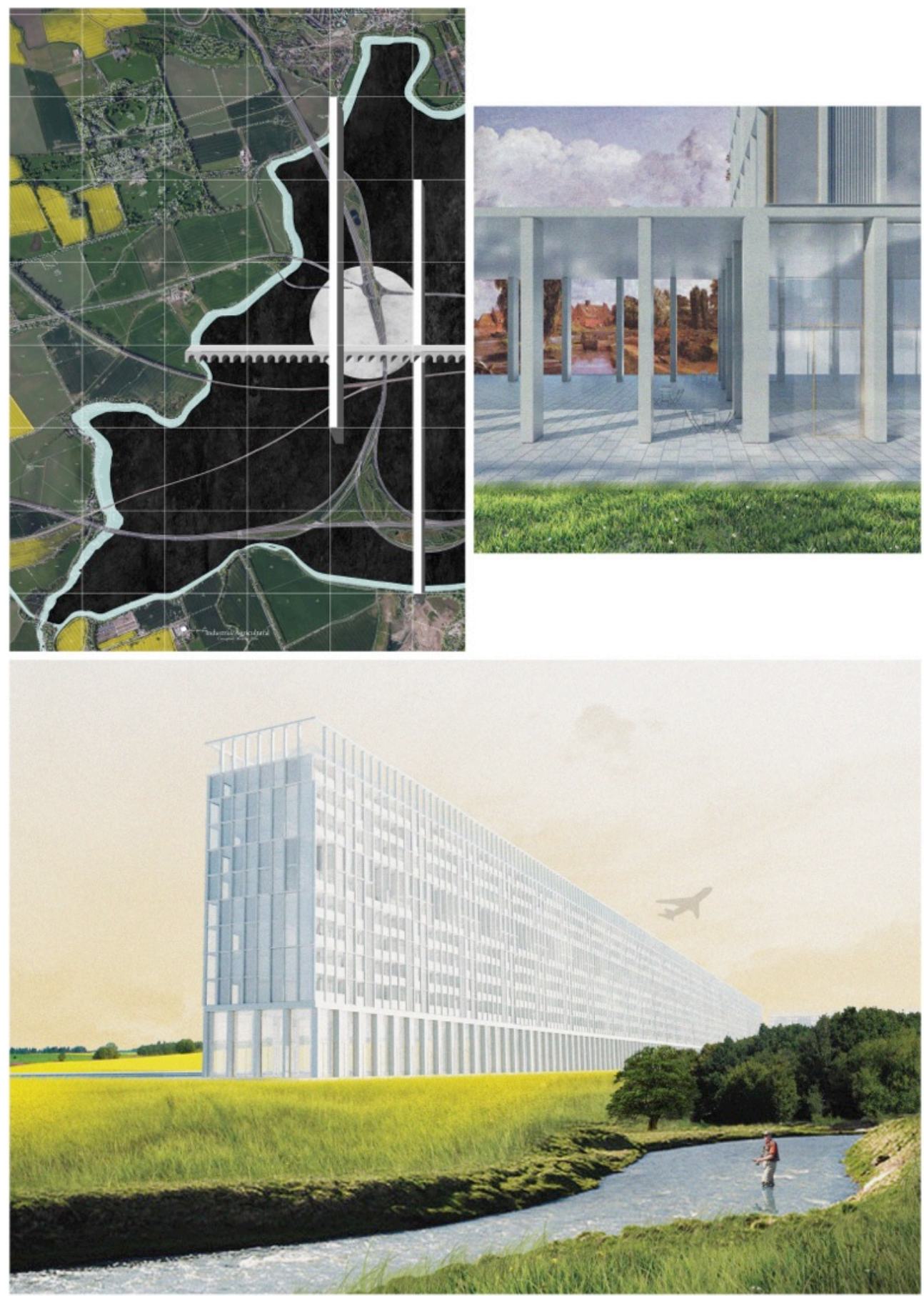

5 Matthew Gadie, Kirsten Pont, Athina Ralli, Li Zhen Ng, Newbridge: Slabs and Frames, Session 2016-17. Long slabs mix with monumental infrastructural typologies to organise the horizontality of a city edge site. Images arranged by Cameron McEwan. 